\title{
Memória e liminaridade entre discursos biográficos da História, do Jornalismo e da Literatura ${ }^{1}$
}

\section{Memory and liminality among biographical discourses of History, Journalism and Literature}

\author{
Juracy Ignes Assmann Saraiva ${ }^{2}$ \\ Claudia Schemes ${ }^{3}$ \\ Denise Castilhos de Araujo ${ }^{4}$
}

\begin{abstract}
Realizo interiormente todas essas ações, no grande palácio da memória. Encontram-se aí, à minha disposição, céu, terra e mar, com aquilo tudo que neles colher com os sentidos, excetuando-se apenas o que esqueci. É aí que encontro a mim mesmo, e recordo as ações que realizei, quando, onde e sob que sentimentos as pratiquei. Aí estão também todos os conhecimentos que recordo, seja por experiência própria ou pelo testemunho alheio. (Santo Agostinho)
\end{abstract}

\section{RESUMO}

O artigo enfatiza a importância da memória na constituição das identidades e, para tanto, visualiza sua manifestação em discursos biográficos da História, do Jornalismo e da Literatura. Por meio de uma análise interdisciplinar, expõe concepções que orientaram a valorização da biografia nesses campos das Ciências Humanas e estabelece aproximações e distanciamentos entre eles, enfocando, particularmente, a relação entre ficção e realidade. A opção pelo biografismo justifica-se pela relevância que esse gênero textual assume na reconstrução de realidades e na preservação da memória e por provocar reflexões sobre os limites entre a narrativa histórica, jornalística e literária.

Palavras-chave: Biografia. Memória.História. Jornalismo. Literatura.

\footnotetext{
${ }^{1}$ Artigo produzido no âmbito de projetos de pesquisa que têm apoio da FAPERGS e do CNPq.

${ }^{2}$ Pós-doutora em Teoria Literária, Doutora em Letras, professora do curso de Letras e do Mestrado em Processos e Manifestações Culturais e pesquisadora do grupo de pesquisa Linguagens e Manifestações Culturais da Universidade Feevale (Novo Hamburgo/RS). juracy@feevale.br

${ }^{3}$ Doutora em História, professora dos cursos de História e Moda e do Mestrado em Processos e Manifestações Culturais e pesquisadora do grupo de pesquisa Cultura e Memória da Comunidade da Universidade Feevale (Novo Hamburgo/RS). claudias@feevale.br

${ }^{4}$ Doutora em Comunicação Social pela PUCRS. Mestre em Semiótica pela Unisinos/RS. Pesquisadora do Grupo de Estudos Memória e Cultura da Comunidade da Universidade Feevale. Professora do Mestrado em Processos e Manifestações Culturais, e dos cursos de Comunicação Social e Design, (Novo Hamburgo/RS). deniseca@feevale.br
}

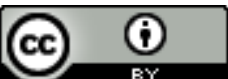

Esta obra foi licenciada com uma Licença Creative Commons - Atribuiç̃a 3.0 Não Adaptada. 


\begin{abstract}
The article emphasizes the memory importance in the identity constitution and, for this, visualizes its manifestation in biographical discourse of History, Journalism and Literature. Through an interdisciplinary analysis, exposes conceptions that guide the biography valorization in these Human Science fields and establishes similarities and differences among them, focusing, in particular, the relation between fiction and reality. The option for biographism is justified by the prominence that this textual gender assumes in the reality reconstructions and in the memory preservation and by provoking reflections about the limits between the historical, journalistic and literary narrative.
\end{abstract}

Key-words: Biography. Memory. History. Journalism. Literature.

\title{
1 MEMÓRIA E IDENTIDADE
}

Ao enaltecer a capacidade de tornar presentes ações, experiências, sentimentos, conhecimentos, revividos por meio de imagens sensoriais, Santo Agostinho enfatiza o poder da memória de instituir a própria subjetividade ao afirmar: "é aí que encontro a mim mesmo" (s.d. p. 274-276). O sentimento de perda ou de dispersão, que acompanha o ser humano e continuamente denuncia sua finitude, encontra, na evocação do passado, uma forma de resistência contra a perda da identidade ou, em outras palavras, contra o esquecimento que, em certo sentido, equivale à morte.

Sob esse aspecto, o Bispo de Hipona recupera a importância atribuída pelos gregos ao culto da deusa Mnemosyne, já que, para eles, a instalação da identidade coletiva e individual depende da memória. Ao conferir aos poetas e historiadores o dom de voltar ao passado, a deusa Ihes transfere a função de enunciar feitos heróicos e de instituir o campo da alétheia ou da verdade que, embora seja concebido por meio de formas simbólicas, é aceito como se correspondesse ao próprio real (MEDEIROS, $X X X)$. Assim, o canto poético ou a palavra do historiador têm o poder de construir, por meio da memória, a identidade de um povo, de dominar a fugacidade do tempo, de representar a totalidade e de preservar as vozes dos enunciadores do esquecimento, graças ao poder sobrenatural de Mnemosyne, cujas qualidades se transferem àqueles 
a quem a deusa distingue com seus dons, porque suas obras os tornam memoráveis e imortais.

"A memória é a mais épica de todas as faculdades," afirma Walter Benjamin (1985, p. 210) ao defender a importância da relação de proximidade entre o narrador e seu ouvinte e distinguir a experiência como condição que confere autoridade a quem narra, ao mesmo tempo em que deplora a falta dessa condição em narrativas da modernidade. Entretanto, a sabedoria, gerada pela memória e pela experiência, e o desejo de resguardar o vivido se mantêm no mundo contemporâneo; nele preserva-se, igualmente, a importância de diferentes modalidades de narrativas e o estabelecimento de uma memória comum que elas transmitem. Essa memória garante aos indivíduos os vínculos que lhes possibilitam integrar-se à história humana e situar-se diante de sua própria finitude; além disso, ela forja uma identidade coletiva, em face da qual a identidade individual desenha seus contornos próprios.

Portanto, a força inspiradora de Mnemosyne - que motivou a criação e a preservação da identidade dos gregos - e o poder do "palácio" da memória - que permite a Santo Agostinho reconhecer sua individualidade -, não desapareceram com as transformações da história humana e do modo de narrar. Eles se manifestam, sobretudo, nas narrativas de caráter biográfico ou autobiográfico, ainda que sejam provenientes do campo da História, do Jornalismo ou da Literatura. Assim, embora preservem suas especificidades, essas narrativas recorrem à função antropológica da memória para conceber a representação de um mundo que deve parecer verídico ou para instalar um universo romanesco que, todavia, deve ser convincente. Dessa forma, a rememoração serve de subterfúgio para a instalação de gêneros distintos, em relação aos quais é possível identificar vínculos de semelhança e de diferenças.

\section{HISTÓRIA E BIOGRAFIA}

Durante muito tempo, pressupunha-se que a História só poderia ser considerada séria e confiável se relatasse as trajetórias de vida de personagens ilustres, 
responsáveis por acontecimentos já consagrados pela historiografia oficial. A partir dessa ótica, os sujeitos desconhecidos e anônimos não eram dignos de pesquisa e de atenção. Entretanto, muitos historiadores sentiam-se insatisfeitos com as limitações impostas pelas correntes historiográficas tradicionais e romperam barreiras por elas impostas, dando forma a novas maneiras de expressar este passado e seus sujeitos, entre elas, a biografia.

No âmbito da História, o gênero biográfico não é recente, e ele passou a ser mais prestigiado a partir do século XVIII, impulsionado pela defesa dos direitos individuais da Revolução Francesa (PEREIRA, 2000, p.117). Entretanto, o interesse por trajetórias individuais tem se mostrado mais intenso nos últimos anos, quando o sujeito retorna ao centro da História, deixando de ser um mero coadjuvante das forças estruturais.

A biografia, de certa forma, contesta a história tradicional, pois "critica a valorização excessiva das grandes estruturas sociais e econômicas e recupera o sujeito na história" (XAVIER, 2000, p.161-2), assinalando o papel dos indivíduos, retomando o interesse pela progressão narrativa e problematizando as fronteiras entre a história e a ficção. Nesse sentido, abandona o recorte de temas específicos como a economia, a política, a sociedade, "objetos por excelência da História," (GUARINELO, 2004, p.16) para fazer emergir, por meio da força enunciadora da memória, um passado contextualizado e vivido.

Assim, o retorno da biografia relaciona-se com a mudança na concepção de História, ou seja, com a passagem do paradigma moderno ou iluminista, para o pósmoderno. No primeiro, a História é analítica, estrutural, explicativa e racional, sendo desconsiderados o acaso, a subjetividade e o irracionalismo; no paradigma pósmoderno, que, segundo Reis (2000), pode ser desdobrado em duas fases - a estruturalista e a pós-estruturalista -, a História revê suas posições, possibilitando a emergência de olhares marcados pela subjetividade.

Com efeito, o Estruturalismo desconfia e descentra o sujeito e a história, questiona a consciência e a razão, opõe-se ao conhecimento especulativo, pois este seria metafísico e estaria vinculado à legitimação de poderes ameaçadores. Entretanto, nele ainda persiste um esforço de buscar a "verdade histórica", o que o vincula ao 
iluminismo ingênuo (REIS, 2000). O Pós-Estruturalismo, por sua vez, radicaliza as teses estruturalistas e se afasta do lluminismo e do discurso da razão:

Os pós-estruturalistas não buscam mais verdades históricas nem aparentes,
nem essenciais, nem manifestas, nem ocultas. Eles recusam essências
originais e fundamentais que se deveriam reencontrar e coincidir. A
fragmentação é levada ao extremo. O universal não é pensável. A subjetividade
pós-estruturalista é antípoda da subjetividade modernista: fragmentada e
descentrada, marcada por diferenças e tensões, contradições, ambigüidades,
pluralidade, nem sonha mais com a unificação. Não há essência ou finalidade,
significado e direção a reencontrar ou realizar. A consciência moderna, a
metafísica da subjetividade essencial, construída pelo iluminismo, é
"desconstruída" pelo pós-estruturalismo. (REIS, 2000, p. 183-4)

É, pois, sob o princípio da desconstrução do discurso da razão que o paradigma pós-estruturalista da história é concebido, possibilitando um olhar diferenciado sobre fatos e sujeitos. Nesse contexto epistemológico, a biografia e as autobiografias ganham evidência, mas, diferentemente das manifestações históricas tradicionais, nelas se expõe a análise pessoal e não a busca de uma verdade estrutural, revelada por uma consciência que se deseja objetiva e neutra. Portanto, o conhecimento histórico, a partir dessa concepção, não é mais passivo e tampouco tende ao universal, visto que permite múltiplos olhares, interpretações de interpretações, acolhendo histórias de vida, biografias, o universo dos que estavam excluídos e que agora assumem um lugar na história.

A mudança de perspectiva não significa que a História deixe de se preocupar com as estruturas que compõem a sociedade, mas essas passam a ser traçadas a partir de um evento, uma vida ou uma prática social, partindo-se do pressuposto de que não há um olhar homogêneo, absoluto. Por conseguinte, a "história global" foi substituída pela "história em migalhas" (REIS, 2000), em que o historiador pode abordar qualquer tema sob qualquer perspectiva.

\footnotetext{
$\mathrm{Na}$ verdade, parece-nos, não houve nessa recusa da história global uma rejeição da racionalidade histórica, mas, pelo contrário, uma radicalização da racionalidade nova, introduzida pelo ponto de vista das ciências sociais. Segundo esta, o todo é inacessível e só pode abordar a realidade social por partes, conceitualmente, e sem juízos de valor, isto é, sem referência a um "dever ser", que introduziria a perspectiva de um futuro no presente-passado. Nesse sentido, a nouvelle histoire, continuando a tradição dos fundadores, realiza e não se distancia desse ponto de vista das ciências sociais: ela não explica mais a realidade global, mas somente tematiza-descreve-analisa partes dela, utilizando a tecnologia mais sofisticada e o texto conceitual-narrativo mais rigoroso. (Ibidem, p.203)
}

Cad. de Pesq. Interdisc. em Ci-s. Hum-s., Florianópolis, v.12, n.100, p.126-158, jan/jul 2011 
Em decorrência dessas balizas teóricas, define-se a biografia como a história de um indivíduo redigida por outro, mas com a preocupação de revelar não apenas a vida do sujeito biografado, mas também a relação de suas ações com fatos históricos. A biografia é, portanto, intermediada pela presença do pesquisador e pelo registro escrito que é elaborado a partir de documentos, arquivos pessoais e relatos das pessoas próximas do sujeito pesquisado. Ela se concretiza, pois, por meio de um texto narrativo, cuja realização resulta de recortes, montagens e traduções de depoimentos orais para escritos, não estando isenta da interpretação do pesquisador. Ela difere da narrativa autobiográfica, em que o próprio narrador constrói seu texto sem a intermediação de outro sujeito produtor, e das narrativas biográficas ou autobiográficas literárias, em que a ficção predomina e que inexiste a obrigatoriedade de um método de investigação, sendo, antes, um estilo de narrativa (RICCl, 2000, p.154).

Entretanto, a adoção do atual paradigma não anula as dificuldades encontradas pelos historiadores em compor biografias. Elas podem apresentar um posicionamento ambíguo do pesquisador que ora denuncia a irredutibilidade dos sujeitos às normas gerais de uma sociedade, ora demonstra como esses mesmos sujeitos se submetem às regras sociais (LEVI, 1998, p.167). Outra ambiguidade da biografia é que ela tanto pode ser um instrumento da pesquisa social quanto estabelecer, ao contrário, uma forma de evitá-la, pois o indivíduo, ao mesmo tempo que tem limites claros e um número restrito de relações significativas, vivencia incontáveis aspectos que um historiador não conseguirá explorar na totalidade. Um terceiro aspecto problemático situa-se na percepção dos historiadores que podem imaginar os biografados como atores históricos que obedecem a um modelo de racionalidade anacrônico e limitado, o que, de fato, não acontece.

Estas questões exigem que o historiador reconstrua o contexto em que vive e age o biografado, pois existe uma diferença entre o personagem social e a percepção que este indivíduo tem de si mesmo. Segundo Giovanni Levi, em certas épocas, a construção da noção de individualidade era muito restrita, e o que era socialmente determinante encobria o que a própria pessoa considerava essencial (Ibidem, p.170). O mesmo autor afirma que essa questão é, na atualidade, expressa com clareza, da 
mesma maneira como o foi no século XVIII, quando surgiu o gênero narrativo biográfico no âmbito da História.

Todavia, isso não elimina os problemas do historiador na escrita de biografias, pois ele se defronta com a complexidade da identidade dos sujeitos, sua formação progressiva e não linear e suas contradições.

A biografia continuou a desenvolver-se, mas de forma cada vez mais controversa e problemática, relegando ao segundo plano aspectos ambíguos e irresolutos que me parecem constituir hoje um dos principais focos de confronto na paisagem historiográfica. Como pano de fundo, temos uma nova abordagem das estruturas sociais: em particular, a reconsideração das análises e dos conceitos relativos à estratificação e à solidariedade sociais nos induz a apresentar de modo menos esquemático os mecanismos pelos quais se constituem redes de relações, estratos e grupos sociais. A medida de sua solidariedade e a análise da maneira pela qual se fazem e desfazem as configurações sociais levantam uma questão essencial: como os indivíduos se definem (conscientemente ou não) em relação ao grupo ou se reconhecem numa classe? (Ibidem, p.173)

Dadas as dificuldades e a complexidade da perspectiva biográfica, hoje os historiadores se utilizam de diversas abordagens para tratar das trajetórias individuais. Uma delas concentra o estudo biográfico não em uma pessoa singular, mas sim na representação de um indivíduo que concentra as características de um grupo, procedimento que, na Literatura, conduz à configuração de personagens típicas. Outra abordagem leva o contexto em consideração, partindo do pressuposto segundo o qual uma vida não pode ser compreendida apenas através de suas singularidades; ela se mostra, igualmente, a cada desvio em relação às normas, desvio que ocorre em um contexto histórico que o justifica. Logo, a história do indivíduo deve ser contextualizada, uma vez que ele mantém uma relação de exterioridade com o tempo em que viveu, não sendo apenas um autômato, colocado num espaço já formatado (SCHMIDT, 2000).

Quanto à interação sujeito-contexto, Schmidt (2000) afirma que existe uma tensão entre o sistema normativo de uma sociedade e a liberdade de ação dos indivíduos, tensão que é um dos fundamentos do pensamento ocidental, sendo as biografias uma forma privilegiada para refletir sobre ela. Sob esse ângulo é que a contextualização deve ser pensada, pois, segundo a teoria funcionalista, o comportamento social é explicado pelo contexto. O contexto também pode ser 
explicado através da cultura, onde as atividades, comportamentos e instituições constituem o lugar da inteligibilidade das linguagens (Ibidem).

Carlos Rojas (2000, p.33) também analisa a relação do indivíduo com o contexto dizendo que, durante muito tempo, havia duas formas ineficazes de interpretá-la: a primeira enfatizava a dimensão do indivíduo em detrimento do contexto, ou seja, o contexto era visto como um simples cenário para a reconstrução biográfica; a segunda era simetricamente oposta à primeira, uma vez que o contexto era responsável pela geração do indivíduo. Para o autor, o indivíduo deve ser abordado no contexto, ele é criador e fruto desse contexto, e é nessa perspectiva dialética que se encontra o centro da problemática do gênero histórico-biográfico.

Um estudo biográfico também pode ser desenvolvido por meio de procedimentos dialógicos, em que a troca e a alternância contínua de perguntas e respostas tornam o material biográfico intrinsecamente discursivo, sem, todavia, conseguir apreender sua natureza real e a totalidade de significados que pode assumir, pois estes somente podem ser interpretados (LEVI, 1998).

Com efeito, é impossível realizar uma pesquisa biográfica tendo em mente que os indivíduos possuem uma vida coerente e orientada para um determinado fim, único e objetivo. A esse respeito, Bordieu afirma que

Produzir uma história de vida, tratar a vida como uma história, isto é, como o relato coerente de uma seqüência de acontecimentos com significado e direção, talvez seja conformar-se com uma ilusão retórica, uma representação comum da existência que toda uma tradição literária não deixou e não deixa de reforçar. [...] o advento do romance moderno está ligado precisamente a esta descoberta: o real é descontínuo, formado de elementos justapostos sem razão, todos eles únicos e tanto mais difíceis de serem apreendidos porque surgem de modo incessantemente imprevisto, fora de propósito, aleatório. (BORDIEU, 1998, p.185)

Portanto, Bordieu critica os teóricos que tratam das biografias como um conjunto coerente e orientado que deve ser apreendido como expressão unitária e objetiva de um projeto de vida, com uma ordem lógica e cronológica, evidenciando, ao contrário, o que a produção romanesca da modernidade tem expressado em sua escrita: a descontinuidade do real, a justaposição e a imprevisibilidade de seus elementos, fato que possibilita aproximações provisórias da realidade, mas jamais sua apreensão total e plena.

Cad. de Pesq. Interdisc. em Ci-s. Hum-s., Florianópolis, v.12, n.100, p.126-158, jan/jul 2011 
Diante do exposto, conclui-se que a construção de uma identidade, tal como a pretendida pela narrativa biográfica tradicional, não é mais possível. Hoje, concebem-se as identidades dos indivíduos como sendo plurais, contraditórias e paradoxais, como lembra François Dosse (2009, p.407):

A identidade biográfica acha-se confrontada com a travessia do tempo, e sofre nesse percurso alterações múltiplas que suscitam uma incessante alteração das linhas segundo ritmos não lineares, a partir de quebras temporais, de fenômenos tardios e de um futuro do passado que ultrapassa os limites biológicos da finitude da existência.

A prática do historiador, como diz o autor citado, deve estar sempre aberta a novas interpretações, a revisitações e não pode fechar-se em singularidades e objetividades impossíveis de serem alcançadas.

\section{JORNALISMO E BIOGRAFIA}

A produção jornalística de narrativas biográficas tem origem nos romances em folhetim, cujo surgimento ocorreu na França, mais precisamente no ano de 1836, coincidindo com o apogeu do Romantismo, já então em sua fase social (MEYER, 1996). A ideia da publicação de narrativas romanescas em fascículos se deve aos responsáveis pelos periódicos La Presse e Le Siècle, que queriam criar uma "isca" para atrair assinantes. Desde seu lançamento, o romance-folhetim converteu-se em grande sucesso de público, principalmente devido à sua forma de publicação, em "fatias" seriadas, que, além de ser mais acessível financeiramente, apresentava-se como meio para a divulgação de novos autores. Assim, praticamente todos os romances passaram a ser publicados dessa forma, e sua aceitação pelo público é que definia o futuro lançamento do material em livro.

A experiência conjugava-se à eclosão de um jornalismo popular, instalado principalmente na França e na Grã-Bretanha, que incorporava a publicação de jornais à lógica capitalista. Publicar narrativas literárias em jornais proporcionava um significativo aumento nas vendas e possibilitava uma diminuição nos preços, o que aumentava o número de leitores, atingindo, ainda, os escritores, que ganhavam mais visibilidade, e os anunciantes, que pagavam mais caro pelos espaços (PENA, 2006, p. 29). 
No Brasil, o romance-folhetim não demorou a conquistar o sucesso que obtivera na França, sendo publicadas produções de Eugène Sue, de Alexandre Dumas, de Octave Feuillet, em variados veículos. Deve-se, pois, à "fulgurante e rápida penetração do folhetim francês à constituição, no Brasil, nas décadas de 1840 e 1850, de um corpo de leitores e ouvintes, consumidores de novelas já em número suficiente para influir favoravelmente na vendagem do jornal que as publica e nos livros que as retomam" (MEYER, p. 292). Por essa razão, autores brasileiros passaram a ter seus romances publicados nos jornais brasileiros, como o Jornal do Comércio, o Correio Mercantil, a Gazeta de Notícias, Jornal das Famílias, destacando-se, entre eles, Manuel Macedo, José de Alencar, Manuel Antônio de Almeida, Aloísio de Azevedo, Machado de Assis. Instalava-se, assim, a tradição da mescla entre literatura e jornalismo que encontraria na crônica do final do século XIX e do início do século XX sua melhor forma de convergência.

Todavia, de acordo com Pena (2006), ainda no século XX, houve a ruptura entre a Literatura e o Jornalismo, principalmente em virtude das alterações estilísticas da linguagem e dos recursos gráficos dos jornais. Com efeito, o Jornalismo passou a perseguir, em suas produções textuais, a objetividade e a concisão, substituindo as narrativas longas, características da Literatura, por textos curtos e impessoais. Em torno de 1950, o objetivo principal dos jornais passou a ser a "novidade e os fait divers assumem a função principal na pauta. A Literatura é apenas um suplemento" (PENA, 2006, P.40). Entretanto, para divulgar a literatura, surgem os "cadernos literários", espaços destinados, exclusivamente, ao lançamento e ao comentário de obras literárias, em que os traços da linguagem jornalística - a clareza, a objetividade, a concisão - também estão presentes.

Na década de 1960, porém, muitos jornalistas manifestavam sua insatisfação em relação à forma que deveriam seguir para a elaboração de seus textos, em que objetividade era elemento essencial. Essa insatisfação levou ao movimento conhecido por Novo Jornalismo, que prega o envolvimento do jornalista no que é narrado e permite a emergência de sua subjetividade nos textos, característica antes bem vista, somente, na literatura. Sob essa perspectiva, na elaboração de seus textos, o jornalista deveria reconstruir o cenário da história, registrar diálogos, considerar o ponto de vista 
de cada um das personagens envolvidas e registrar elementos como hábitos, roupas, gestos, características significativas dos envolvidos (PENA, 2006). Para a elaboração de um texto com tais características, necessariamente, o jornalista deveria envolver-se afetivamente, a fim de assimilar, dos entrevistados, todas as informações necessárias para a composição de sua matéria.

Atualmente, nos Estados Unidos, é possível observar o uso da expressão "novo jornalismo", que se caracteriza pela exploração de fatos do cotidiano, ou seja, dos acontecimentos ordinários, do que acontece no dia a dia, com a intenção de questionar os fatos, em uma atitude quase ativista (PENA, 2006). Nesse novo jornalismo, que ocupa espaço nos jornais do Ocidente, o envolvimento do jornalista com as personagens e os fatos é intenso, e os relatos são elaborados com informalidade, muitas vezes na tentativa de reconstruir a "fala das ruas" ou das personagens envolvidas nas ações.

Diante dessa mudança, parece inevitável que tantos jornalistas, no mundo todo, sejam responsáveis pela escrita de biografias, gênero textual que faz parte do jornalismo literário e se caracteriza pela narrativa da vida de uma personagem (PENA, 2006). Um dos fatos que pode justificar o envolvimento dos jornalistas com o gênero talvez seja a busca insistente desses profissionais pela realidade que cercava os biografados, ainda que a representação dos fatos vividos por esses indivíduos se situe não no plano da verdade, mas no da verossimilhança.

$\mathrm{Na}$ narrativa biográfica, o jornalista toma a si a tarefa de apresentar aos leitores a vida, de forma detalhada, de determinado indivíduo (Wolfe apud Pena, 2006). Para atender a esse objetivo, o escritor deve apresentar aos leitores os fatos que marcaram a vida do objeto da biografia, bem como aquelas pessoas que compartilharam situações, vivências. Nessa apresentação, está em jogo menos a verdade do que a verossimilhança, mas, para que ela se efetive, é necessário que o escritor dê coerência aos fatos vivenciados pela biografado. Muitas vezes, os acontecimentos relatados pelos próprios indivíduos parecem não ter conexão, por isso cabe ao jornalista inter-relacionálos, pois, caso contrário, o leitor não compreenderá a exposição dos eventos.

É importante ressaltar, aqui, a característica que tem um texto biográfico de trazer à tona a memória do indivíduo biografado. Muitos dos textos biográficos 
explicitam a vida privada de indivíduos, gerando nos leitores a curiosidade por um lado que, muitas vezes, era totalmente ou em parte oculto dos fãs. Esse desvelar parece fazer surgir uma aproximação entre as duas partes, pois o leitor passa a conhecer um pouco melhor a vida do biografado, compartilhando com ele certas situações desconhecidas até então. O indivíduo biografado parece sair de um lugar mais distante, o lugar das celebridades, e pousar na vida cotidiana dos leitores. Para Schmidt (1997),

\begin{abstract}
Vemos também que, atualmente, muitos biógrafos buscam resgatar facetas diferenciadas dos personagens enfocados e não apenas, como nos trabalhos tradicionais, a vida pública e os feitos notáveis dos mesmos. Assim, emergem em seus textos, entre outros aspectos, os sentimentos, o inconsciente, a cultura, a dimensão privada e o cotidiano ( p.13).
\end{abstract}

Uma questão que tem sido motivo de grandes embates em relação à publicação de biografias é o caráter privado ou público da vida dos indivíduos. Sabe-se que muitas biografias geram discussão entre o autor do texto e os herdeiros ou o próprio indivíduo biografado. Schmidt (1997) comenta:

[...] quero mencionar um outro aspecto importante, relacionado com a elaboração e publicação de biografias: a questão ética. Até que ponto podemos invadir a vida de um personagem, expor seus segredos, explicitar suas mazelas? O biógrafo pode apropriar-se da imagem de seu biografado? (p.14)

A exposição pública de fatos, situações ou de vivências de um indivíduo, sem o seu claro consentimento, tem gerado muitas discórdias no meio publicitário. Um dos últimos embates acompanhados pela imprensa foi a proibição da venda da biografia do cantor Roberto Carlos - Roberto Carlos em Detalhes. Texto elaborado e publicado sem prévia autorização do cantor, mas que foi, durante certo período, vendido em livrarias de todo o país.

Outro aspecto interessante que se observa hoje na estreita ligação entre biografias e jornalistas é a existência de alguns biógrafos tão famosos quanto seus biografados. E, diante de alguém reconhecido no meio como autor dessas produções, esse indivíduo pode escolher que personalidade gostaria de biografar, independentemente de ser ou não muito conhecido ou reconhecido pelos futuros leitores (PEREIRA, 2007).

No Brasil, atualmente, destacam-se, como biógrafos, Fernando Morais e Ruy Castro. Fernando Morais é autor de Olga (1985 - biografia de Olga Benário), de Chatô: 
o rei do Brasil (1999 - biografia de Assis Chateaubriand) e de O mago (2006 - biografia de Paulo Coelho). Sua narrativa caracteriza-se pelos detalhes, os quais, segundo o autor, são fruto de pesquisas exaustivas (PENA, 2006).

O outro biógrafo, Ruy Castro, é autor de Anjo pornográfico (1992 - biografia de Nelson Rodrigues), Estrela Solitária (1995 - biografia do jogador de futebol Garrincha), e Carmen (2005 - biografia da cantora Carmen Miranda). Para Castro, o segredo de uma biografia está na apuração dos dados que o autor deve realizar (PENA, 2006).

Nas últimas décadas, as editoras têm investido nas narrativas biográficas, pois são histórias que encontram inúmeros leitores interessados na sua leitura. Entretanto, em artigo publicado pela Folha de São Paulo, de 5/12/04, quatro diretores de editoras brasileiras apresentam opiniões divergentes acerca das narrativas. O diretor da Cia das Letras, Luiz Schwartz afirma que, nos últimos anos, esse gênero textual "vem crescendo no mundo todo" (BUARQUE, 2004). Por outro lado, a opinião de Luciana Villas-Boas é de que "não é qualquer biografia que desperta o interesse do público, a qualidade não é sinônimo de sucesso editorial e o gênero não é fácil de trabalhar", referindo-se a várias biografias que a editora já publicou, mas as quais não atingiram a venda esperada (BUARQUE, 2004). Outros dois editores afirmam que o mercado das biografias não está em crescimento, informando, inclusive, que já foram vendidos mais livros desse gênero no país (BUARQUE, 2004).

Apesar de não haver concordância no que diz respeito ao aumento ou não das vendas de textos biográficos, o que se sabe é que a maioria das grandes livrarias disponibiliza um espaço para esse gênero textual (Vilas Boas, 2002).

\section{PERCURSO DA BIOGRAFIA LITERÁRIA E SEU ENLACE COM A HISTÓRIA E O JORNAL}

A palavra biografia origina-se dos vocábulos gregos bios, que significa vida, e gráphein que se refere à ação de gravar, desenhar, registrar, conceber um tratado ou estudo; o último termo centraliza também a ideia de escrita, como em grafia, estando 
presente em termos como caligrafia e historiografia. A etimologia da palavra biografia abrange, portanto, o registro de vidas que podem ser narradas oralmente ou por escrito, desenhadas, pintadas ou encenadas. Essa abrangência em termos de linguagens ou, em outras palavras, de formas de expressão, vincula as biografias a relatos da oralidade, em que a palavra, ou traços, linhas, cores, gestos aliaram-se à memória, para opor-se ao esquecimento das histórias dos heróis e de seus feitos. Entretanto, é com a difusão da escrita que o biografismo ou o "espaço biográfico 5 " - no qual a biografia se inclui - ganha um novo aliado para sua manifestação, podendo-se localizar a propagação do registro escrito das histórias de vida, no âmbito da cultura ocidental, no século IV a.C., momento em que as formas estruturais da biografia conjugam-se às da ciência da História.

Segundo Pierre Henri Larcher, Heródoto de Halicarnasso (420 a.C. - 485 a.C.?), "ao escrever a sua História, teve em mira evitar que os vestígios das ações praticadas pelos homens se apagassem com o tempo e que as grandes e maravilhosas explorações dos Gregos, assim como as dos bárbaros, permanecessem ignoradas" (Heródoto,1950, s.p.). Nos livros de Heródoto, confunde-se a história dos heróis com a dos eventos, no desejo de expor a motivação das ações humanas. De modo semelhante, conduz-se Platão ao compor seus diálogos, pois ele recorre a pessoas de existência real para transformá-las em personagens, atribuindo-lhes opiniões e posicionamentos em face de questões como a do processo criativo - tratado em Íon ou Da llíada -, ou da concepção de sabedoria - manifestada em Cármides, em que um belo aristocrata se vangloria de ser possuidor de uma mente sábia, sem, contudo, ser capaz de definir essa virtude. ${ }^{6}$

\footnotetext{
${ }^{5}$ A expressão "espaço biográfico" foi criada por Philippe Lejeune(1975) para denominar as variadas formas de expressão linguística que abrangem a biografia, a autobiografia, o autorretrato, memórias, confissões, diários íntimos, textos ensaísticos e epistolares. Em todas essas modalidades textuais, há sempre uma vida a ser contada, destacando-se, que, neste artigo, tem-se presente a diversidade que pode recobrir o termo biografia, razão por que, em seu lugar, também há a utilização da expressão espaço biográfico e do termo biografismo, mantendo-se os termos biografia e autobiografia para esses subgêneros ficcionais específicos.

${ }^{6}$ Os 35 diálogos de Platão foram escritos em diferentes estágios da vida do filósofo e, em sua maioria, são intitulados por meio de nomes, como se constata nos seguintes exemplos: Críton ou Do Dever, Eutífron ou Da Santidade, Lísis ou Da Amizade, Crátilo ou Da Etimologia, Ménon ou Da Virtude, Fédon ou Da Alma, Fedro ou Da Beleza, Filebo ou Do Prazer. As obras de Platão. Disponível em:http://www.educ.fc.ul.pt/docentes/opombo/hfe/momentos/escola/academia/obrasplatao.htm. Acesso em: nov. 2010.
}

Cad. de Pesq. Interdisc. em Ci-s. Hum-s., Florianópolis, v.12, n.100, p.126-158, jan/jul 2011 
O hibridismo do discurso, simultaneamente filosófico, teológico, poético, mas apoiado em referências biográficas, também está presente na tradição judaico-cristã e em manifestações da Roma Antiga. O Antigo Testamento é constituído por diferentes ciclos, cada um deles dedicado ao reconhecimento de um protagonista; abrangendo as histórias de Abraão, Moisés e de outras personagens bíblicas, apresenta, com o Livro de Jó, um expressivo exemplo de texto de tom confessional. Esse também se evidencia nas Epistulae morales, dirigidas por Sêneca (4-65) ${ }^{7}$ ao seu discípulo e amigo Lucílio, na obra Meditações, do imperador Marco Aurélio 121-180), que expressam a moral da antiguidade pagã. Sem ater-se ao confessionalismo, o enfoque na biografia dos indivíduos também é característico da obra de Públio Cornélio Tácito (55-120), autor de Annales e Historiae - que narram o primeiro século do Império Romano -, e de Caio Suetônio (69-141), que escreve As vidas dos doze Césares. Entretanto, o mais representativo texto biográfico da Antiguidade são as Confissões de Santo Agostinho (354-430), em que, por meio de um diálogo com Deus, ele narra sua vida e, especialmente, sua conversão espiritual ao cristianismo, narrativa que é enriquecida pela introspecção psicológica e pelas especulações filosóficas e teológicas.

$\mathrm{Na}$ Idade Média, as narrativas de vidas exemplares ou heróicas ganham espaço nas hagiografias, inscritas em textos verbais e visuais, e nas narrativas de cunho mítico e histórico. Embora tenha iniciado na Igreja primitiva, a literatura hagiográfica cristã se desenvolveu com a expansão do cristianismo e a difusão do culto aos santos, sendo uma forma de propagar concepções religiosas e padrões morais e axiológicos. Isso se constata nas histórias da vida dos santos, calcadas em tradições orais e em registros escritos em latim ou castelhano, do clérigo secular e poeta Gonzalo de Perceo, que viveu na primeira metade do século XIII no Reino de Castela, ou na Coleção Mystica, registrada por Frei Hylario de Lourinhã, que se encontra no mosteiro cirterciense de Alcobaça (SILVA, s.d, s.p).

Eivadas de fantasia, mas preservando um substrato histórico, as novelas de cavalaria do ciclo francês, cujo protagonista é Carlos Magno, ou do ciclo bretão, cujas

7 "Séneca, filósofo, dramaturgo, estadista, e tutor de Nero, foi um dos mais eminentes escritores da literatura latina no primeiro século da nossa era. A obra que dele nos resta, produzida toda ela nos anos da sua maturidade, reflecte a esmerada formação retórica e filosófica que recebeu e cultivou em Roma". Disponível em: http://malexandre.no.sapo.pt/Docs/AlexandreJunior_2002a.pdf. Acesso em: 20.10.10 
histórias expõem as aventuras dos heróis da Távola Redonda e da corte do Rei Artur, constituem exemplos da ênfase dada às histórias de vida na Idade Média. A Canção de Rolando, expressão do ciclo francês, é uma gesta que trata da emboscada em que morrem o nobre Rolando, sobrinho de Carlos Magno, o arcebispo Turpim e outros cavalheiros, na Batalha de Roncesvales em que os vascones são os oponentes dos franceses, embora, na narrativa, os inimigos sejam representados pelos muçulmanos. No âmbito da literatura portuguesa, são remanescentes do ciclo bretão as novelas José de Arimatéia, A História de Merlim e A Demanda do Santo Graal, a qual narra a busca do cálice sagrado em que José de Arimatéia teria recolhido o sangue de Cristo, empreendida pelos cavaleiros do Rei Artur. Os exemplos mencionados referendam a natureza biográfica da tradição épica da literatura medieval, ainda que elementos míticos e lendários sejam agregados aos personagens e aos eventos históricos que lhe serviram de inspiração (MEDEIROS, 2008).

$\mathrm{Na}$ Alta Idade Média, "personagens das epopéias e dos ciclos lendários foram subsumidos pela interpretação figural, junto a outras formas, alegóricas e simbólicas" (MITIDIERI, p.83). Avulta, no período, o nome de Dante Alighieri (1265-1321), o primeiro poeta da língua italiana, que, em sua Divina Comédia, se vale de figuras lendárias e de pessoas conhecidas como Francesca da Rimini. Embora casada com Giovanni Malatesta, a jovem se apaixona pelo irmão desse, Paolo. Descoberta a relação adúltera, Francesca e Paolo são assassinados por Giovanni. Em sua fantasia poética, Dante expõe o sofrimento dos amantes no canto $\mathrm{V}$, de $\mathrm{O}$ Inferno, onde, como castigo, permanecem eternamente abraçados, para representar o drama dos que se deixam seduzir pelas emoções desenfreadas, suscitadas, neste caso, pela leitura da história de Lancelote e Guinevere.

$\mathrm{Na}$ esteira do período histórico que se estende do século XV ao século XVIII, marcado pelas grandes descobertas e navegações e pela substituição do modelo de produção feudal, igualmente são registradas narrativas épicas em que aspectos históricos e personalidades constituem o núcleo central da diegese. Os Lusíadas, de Camões - em que eventos da história e elementos biográficos contribuem para a composição de um amplo panorama da nacionalidade portuguesa -, ilustram esse procedimento. Também as narrativas de viagens, como Peregrinação, de Fernão 
Mendes Pinto -_que se aventurou pelo Oriente, especialmente pelo Japão e China - e as que revelam o confronto entre o imaginário europeu em face do América recémdescoberta, como as cartas de Cristóvão Colombo, traduzem, em sua diversidade discursiva, a ênfase na perspectiva de um narrador que entrelaça os acontecimentos narrados a sua história de vida.

Todavia, nesse mesmo período, isto é, em 1605, é publicada uma das obras fundadoras da literatura ocidental, que amplia o espectro da biografia: $O$ engenhoso fidalgo Don Quixote de La Mancha. Ao parodiar as novelas de cavalaria, cuja representação textual Don Quixote assume como verídica, Miguel de Cervantes (15471616) dá nova configuração ao gênero biográfico, visto que privilegia a imaginação e o jogo lúdico da linguagem, instaurando o paradigma do romance moderno que mimetiza a realidade para, simultanemante, criticá-la e transcendê-la.

Também situada no final do século XVI e início do século XVII, registra-se a produção de William Shakespeare (1564-1616), que agrega, à recriação de histórias de vida, reflexões sobre a condição humana para denunciar suas mazelas, particularmente, o desejo obstinado da busca de poder, o qual está expresso em peças dramáticas de cunho biográfico, como Ricardo III, Rei João e Henrique VIII. Por representarem embates relativos à ordem social e política, cuja estrutura, uma vez rompida, conduz ao caos, as peças históricas do poeta e dramaturgo inglês constituem inegável fonte de informação sobre o passado da nação inglesa e explicitam laços identitários aptos a traduzirem a memória coletiva de um povo. Sua popularidade deveu-se, porém, em grande parte, ao fato de circularem impressas, estando, pois, acessíveis ao público que, por sua vez, contribuía para sua divulgação.

Entretanto, se Cervantes e Shakespeare assistiram ao aparecimento do livro no contexto europeu, o século XVIII, especialmente em suas últimas décadas, foi marcado por novos avanços tecnológicos e por nova cosmovisão, os quais, por um lado, tiveram influxos diretos na difusão da literatura e, por outro, sedimentaram a concepção de indivíduo, promovendo a valorização do biografismo. A fabricação industrial do papel e o uso da prensa rotativa permitiram que a circulação da palavra escrita se alinhasse "ao modelo em curso da produção anônima e em série, raiz da massificação" (ZILBERMAN, 2001, p. 31). Os avanços tecnológicos propiciaram a expansão dos jornais, que se 
tornaram diários, alargando o espaço das manifestações de circulação impressa, enquanto, simultaneamente, a universalização da escola contribuiu para a formação de leitores. No final do século, devido à defesa do princípio de que a atividade literária deveria estar livre do comprometimento político, "o número de poetas e homens de letras que vivem de suas obras aumenta de dia para dia, exatamente como sucede com o número de pessoas que leem e compram livros" ( HAUSER, 1982, p. 699).

A existência de um público novo e a orientação intelectual proveniente da classe média na Europa Ocidental conjugam-se e influenciam a manifestação de obras com novo padrão estético. Robinson Crusoe e Moll Flanders, de Daniel Defoe (1661-1731), As viagens de Gulliver, de Jonathan Swift (1667-1745), A Vida e Opiniões de Tristram Shandy, de Laurence Sterne (1713-1768), traduziam uma perspectiva inovadora, em que o nacional e o popular se opunham ao universalismo manifestado na literatura clássica; em que os costumes da vida cotidiana emergiam a partir de uma pauta crítica e moralizadora; em que as bases religiosas e filosóficas enfatizavam as virtudes pessoais e sociais em detrimento dos dogmas da fé; em que o racionalismo cedia lugar à exaltação sentimental.

Nesse contexto, avultam, por sua importância na consolidação da ideia de afirmação do individualismo e da defesa da liberdade, os iluministas franceses, Voltaire (1694-1778) e Jean-Jacques Rousseau (1712-1788). O primeiro publicou Candido ou o otimismo, um bildungsroman às avessas, visto que o protagonista, dominado por um otimismo capaz de resistir a toda e qualquer desgraça, vivencia catástrofes cujo fulcro é abstraído da história - como o terremoto que abalou Lisboa em 1755 - e de lendas como a do Eldorado - sem progredir em termos de formação. Com o romance, o autor expõe sua visão sarcástica sobre a religião, os governos, a filosofia, com o intuito de denunciar formas de dominação e de intolerância. Rosseau, por sua vez, inspira-se na história de Heloísa e Abelardo, apresentada pelo próprio filósofo escolástico francês do século XII, em História das minhas calamidades, para escrever La Nouvelle Héloise. Nessa, a paixão amorosa cede lugar à renúncia e à sublimação do sentimento e em que o autor defende o ponto de vista segundo o qual os indivíduos devem obedecer aos preceitos morais da sociedade apenas quando esses estão em consonância com seus próprios princípios. Em As confissões, Rosseau cria um protagonista que narra sua 
própria vida e, ao transpor o desdobramento do sujeito sobre si mesmo, revela o antagonismo entre os menos favorecidos e os níveis superiores da sociedade e um posicionamento narcisista que viria dominar as produções biográficas do Romantismo, de que essa obra e Os sofrimentos do jovem Werther, publicado por Goethe em 1774, são marcos iniciais.

Os anos finais do século XVIII são assinalados, não apenas por formas de expressão individualistas, mas por "um programa definido" em que o individualismo é "um protesto contra a despersonalização inerente ao processo da civilização" (HAUSER, 1982, p.709). Esse posicionamento, que se estende ao século XIX e do qual resulta o investimento em histórias de vida, não se constituíra, até então, como uma problemática, mas viria a caracterizar o romance moderno. Com efeito, o Romantismo centrou-se na valorização do particular, do singular, do íntimo, daquilo que diferencia um indivíduo de outro, dando lugar à produção de uma galeria de heróis cujos retratos eram compostos sob a égide do sentimentalismo. Nas obras, à manifestação dos sentimentos cabia superar o racionalismo neo-clássico e, sobretudo, denunciar a ausência de sentido da vida - orientada apenas para o poder econômico -, enquanto a fantasia e a imaginação superavam a inserção em uma realidade inaceitável e ajudavam a instalar um idealismo alienante.

Dentre os numerosos escritores, adeptos de concepções românticas que investiram em textos marcados pelo biografismo, citam-se, entre os ingleses, Walter Scott (1771-1832), e, entre os franceses, Victor-Marie Hugo (1802-1885) e Alexandre Dumas. Walter Scott, considerado o criador do romance histórico pela crítica inglesa, confere a muitas de suas obras um cunho biográfico, de que são exemplos Ivanhoe e $A$ vida de Napoleão Bonaparte. No drama histórico Cromwell, Victor Hugo centra-se na história de vida do militar e político inglês Oliver Cromwell, que instaurou a república puritana na Inglaterra, em 1649, mas a importância da obra justifica-se, sobretudo, porque o autor faz do prefácio um manifesto em que se opõe às restrições formais do classicismo e em que defende a arte como representação do humano, sendo caracterizada, portanto, pela convergência entre o sublime e o grotesco, o trágico e o cômico. Essa concepção é inscrita por Alexandre Dumas (1802-1870), pai, em dezenas de romances, de contos e de peças teatrais, salientando-se, no âmbito do espaço 
biográfico, em $\mathrm{O}$ Conde de Monte Cristo, Os três mosqueteiro e Memórias de um médico (romance dividido em diversos episódios). Dumas, com suas produções, que eram publicadas em série nos jornais, assim como as de Eugène Sue e Balzac, contribuiu para a difusão da literatura e para o fortalecimento da mídia impressa, pois garantia aos veículos de comunicação um público cativo devido a seus folhetins. Assim, por meio de sua aliança, literatura e jornal concretizam interesses em comum.

Recusando a perspectiva idealizadora e acentuadamente sentimental, Honoré de Balzac (1799-1850), Gustave Flaubert (1821-1880) Fiódor M. Dostoiévski (1821-1881), Léon Tolstói (1828-1910) e José Maria de Eça de Queirós (1845-1900) são outros, entre tantos escritores, que investem nas histórias de vida, mesclando a análise do psiquismo humano e da sociedade à sua capacidade criadora. Balzac traça um panorama da sociedade francesa, que ocupa especialmente o período posterior à queda de Napoleão em 1815 e, valendo-se do substrato histórico, institui personagens cuja densidade Ihes permitiu migrar no tempo, para revelar traços fundamentais do ser humano. Eugénie Grandet, O pai Goriot, Coronel Chabert exemplificam a atualidade das narrativas de Balzac, pois, se a minúcia de costumes reproduz determinada época, encontra-se também aí uma análise do comportamento humano e de seus impasses morais que não são datados, pois fazem parte da essência da humanidade.

Gustave Flaubert abandona a preocupação com as referências factuais, visto que sobrepõe a ela a reflexão sobre as condições necessárias para garantir ao romance o caráter artístico, o que não o impede de proceder à análise dos comportamentos coletivos de seu contexto sócio-histórico. O escritor defende o princípio da objetividade no processo de representação do real e tem consciência de que os efeitos de verossimilhança do romance dependem das estratégias da narração. Ele formaliza suas conviç̧ões por meio de Madame Bovary, romance mediante o qual instala um novo paradigma literário ao eliminar a presença explícita do narrador, para dar lugar ao dinamismo dos próprios acontecimentos, que são captados a partir da subjetividade das personagens. Assim, a impressão de objetividade e o envolvimento do leitor resultam da maneira como são transmitidas as informações, pois o narrador esmaece sua voz para adotar não só a emissão dos juízos dos protagonistas, mas também a abrangência de seu olhar. 
O procedimento induz o leitor a migrar do domínio amplo, mas distanciado dos fatos, próprio da onisciência narrativa, e a aproximar-se da intimidade das personagens: vê através do olhar de Ema ou de Charles Bovary, acolhe suas palavras, emergentes das do enunciador, e capta suas sensações deles, como se inexistissem, entre as personagens e ele, os artifícios da ficção (SARAIVA, 2009, p. 27)

As técnicas composicionais de Flaubert influenciam a recepção de Madame Bovary - o que pode ser salientado pelas contestações e pela censura que recebeu no momento de sua publicação na Revue de Paris e que o levaram aos tribunais - e os aspectos da forma são também responsáveis pela denúncia dos valores da sociedade burguesa, de que os sonhos, comportamentos e frustrações de Ema Bovary são manifestação. Ao harmonizar a técnica com a representação do real, Flaubert inova a arte da narrativa, particularmente a da biografia ficcional, e oferece lições cuja validade e atualidade, sob o ângulo da moral, são incontestáveis, apesar de sua descrença em relação à sociedade burguesa que a obra tão bem retrata.

Fiódor Mikhailovich Dostoievski, em Crime e Castigo, Os Irmãos Karamazov, Memórias do subsolo e O Idiota, mergulha na interioridade do ser humano, desvelando seus conflitos, seus impulsos, desejos inconfessáveis e seus traumas, para inscrever, nos textos, um mundo passional, cuja dimensão não fora ainda alcançada pela arte, nem pela ciência. Esses aspectos estão evidentes no drama de Raskolnikov, protagonista de Crime e Castigo, que vive um conflito moral por ter cometido duplo assassinato; na angústia que envolve os irmãos Ivã, Aliéksiei e Dimitri Karamazov, após o assassinato do pai, visto que, de uma forma ou de outra, todos desejavam sua morte, sentindo-se culpados ainda que não a tivessem perpetrado; no solilóquio do funcionário público aposentado que, em suas Memórias, demonstra o vazio e o sem sentido da existência; na problemática enfrentada pelo príncipe Michkin que, por sua bondade e ingenuidade e por sofrer de epilepsia, é incapaz de se adaptar a uma sociedade obcecada pelo dinheiro e poder, restando-Ihe apenas o sanatório para viver.

Nas narrativas acima mencionadas, em que o caráter biográfico é incontestável, Dostoiévski concentra o foco nos protagonistas, mas não os expõem por inteiro, obrigando o leitor a compor sua imagem pela soma de opiniões e pontos de vista que eles enunciam a respeito de si mesmos ou que revelam uns a respeito de outros. Nesse 
universo multifacetado, emergem temas como a consciência da culpa, o drama do parricídio desejado ou real, a oposição entre misticismo e racionalidade, entre autoritarismo e compaixão, o dilema entre liberdade e submissão e o drama dos indivíduos alheios ao contexto social, porque mergulhados em seu individualismo.

Apesar do predomínio de temas negativos e da falta de unidade da estrutura dramática, "constituindo como que um mosaico" (HAUSER, 1982, p. 1035), os romances de Dostoiévski não refletem um nihilismo desalentador, pois a existência das personagens ganha um significado transcendental que se revela em momentos únicos e especiais, em que elas se encontram consigo mesmas ou com seu destino. Consequentemente perpassa, nos romances, um "otimismo trágico" (Idem, p.1034), base da filosofia de Dostoievski, que se opôs ao pessimismo e ao niilismo, parecendo afirmar, por meio desse posicionamento, que a arte pode ser um veículo capaz de dar forma à irracionalidade da vida.

Guardando, igualmente, um sentido atemporal, as obras Guerra e Paz e Anna Karenina consagram Léon Tolstói como mais um dos grandes escritores do século XIX. A primeira, publicada em partes no periódico Mensageiro Russo, relata a história de cinco famílias aristocráticas e seu vínculo com a campanha de Napoleão Bonaparte na Rússia, abrangendo um período que vai de 1805 a 1820. Embora se detenha nos principais acontecimentos que permitiram ao exército francês a ocupação da Rússia e, posteriormente, sua retirada desse país, Tolstoi, nas palavras de João Gaspar Simões,

quis pintar a paz e a guerra na expressão mais vasta dos seus efeitos. E assim se, por um lado, escolheu para assunto da sua obra uma época capital da história da Rússia, pelo outro julgou de seu dever introduzir no quadro epopéico do povo russo a pintura da sociedade que ele mais de perto conhecia e em que, de fato, se concretizavam, por então, as virtudes e os defeitos duma sociedade que só era civilizada na camada aristocrática. (s/d)

Em Guerra e Paz, não há propriamente um herói cuja vida seja retratada, mas nela se entrelaçam personagens reais com a ficção, incluindo, ainda, ensaios de natureza filosófica. Anna Karenina, concebida sem a inclusão de ensaios, é, para o autor, seu primeiro romance, e sua protagonista, ainda que tenha sido inspirada na filha do poeta Alexander Pushkin, tem contornos tão marcadamente emocionais que inscreve a obra no âmbito da ficcionalidade. Ao compor o drama centrado em uma 
relação adúltera, tema já anteriormente explorado por Gustave Flaubert, Tolstoi transpõe, como o escritor francês, os limites que podem aprisionar a literatura à realidade para afirmar sua autonomia e sua capacidade de mimetizar o real sem assumir uma posição subalterna em relação a ele. Por outro lado, o romance reflete pontos de vista do escritor que estão presentes em sua biografia de 1882, intitulada Confissão, na qual revela seu cristianismo primitivista e sua opção pelo pacifismo.

Como representante da estética realista em Portugal, Eça de Queirós não foge ao biografismo, como se constata pelos títulos de suas obras $O$ crime do padre Amaro e O primo Basílio, mas é em Os Maias e em $A$ Relíquia que a ênfase na história de vidas, articulada à análise da sociedade portuguesa, se destaca. A ação de Os Maias passase em Lisboa, na segunda metade do séc. XIX, e seus episódios se concentram em três gerações da família Maia. O desenlace infeliz do casamento de Pedro da Maia, da segunda geração, instala as condições necessárias para que ocorra uma relação incestuosa entre seus filhos Maria Eduarda e Carlos Eduardo. O incesto parece sugerir uma imagem metafórica do país e da alta burguesia lisboeta, cuja decadência política e cultural é traçada no romance, confluindo para um processo de degradação dos costumes em que o rompimento das mais primitivos preceitos éticos acaba por ser visto apenas como uma decorrência do acaso. Entretanto, é em $A$ Relíquia que Eça assume o gênero memorialístico em sua acepção restrita e em que abandona a observação e a análise da sociedade - expressa pelo olhar de narradores não envolvidos com a história narrada - para traduzi-la pelo olhar cínico de Teodorico Raposo, que apresenta as peripécias de sua viagem à Terra Santa e sua vivência junto à tia beata que o criara. Para conseguir a herança da tia, pretende dar a ela uma imitação da coroa de Cristo, a ser apresentada como relíquia verdadeira, mas, por um equívoco, dá-lhe a camisola de uma amante. A incapacidade de elaborar uma mentira que desse uma áurea de santidade ao presente leva Raposo a perder a desejada herança. A narrativa é um libelo contra a beatice e a hipocrisia e uma crítica mordaz e contundente à sociedade portuguesa, ressaltando-se nela os defeitos do clero. Com efeito, ao escrever Os Maias e A Relíquia, Eça demonstra a função social da literatura que não só reflete a realidade, mas também se posiciona diante dela para modificá-la. 
No período de formação da literatura brasileira, o biografismo contribuiu para instalar as origens da identidade nacional, de que são exemplo os poemas épicos Prosopopéia (1601), de Bento Manuel Teixeira, O Uraguai (1769), de Basílio da Gama, e O Caramuru (1871), de Santa Rita Durão. A modalidade biográfica também se fez presente para afirmar a existência de uma literatura nacional, como se constata nas numerosas produções românticas em que a busca pelo passado histórico e a exaltação de personagens-tipo - representativos da terra e da paisagem brasileira - gerou obras cujos títulos revelam a preocupação em criar histórias de vida, como Ubirajara, Inocência, Lucíola e A escrava Isaura. Entretanto, no percurso da literatura brasileira, apesar da grande incidência do biografismo, três obras podem ser consideradas basilares para a constituição desse gênero no âmbito romanesco, particularmente por sua relação com a história e o jornal e por instituírem narradores que relatam sua própria história de vida: Memórias de um sargento de milícias, de Manuel Antônio de Almeida (1831-1861), Memórias Póstumas de Brás Cubas, de Machado de Assis (18391908), e São Bernardo, de Graciliano Ramos (1892-1953).

Assim como Eça de Queirós em A Relíquia, Manuel Antônio de Almeida empresta um humor crítico e mordaz a sua narrativa e, contrariando os procedimentos da época, nela representa a classe média e baixa, cuja linguagem incorpora ao romance. O espaço físico e social do Rio de Janeiro é apresentado, por meio de uma variada galeria de tipos populares que circula por ruas, igrejas, praças, bares, acampamentos de ciganos, sendo explicitados hábitos, normas de conduta, convicções e crendices religiosas e, sobretudo, a permissividade dos costumes, no que tange às relações sexuais, familiares e profissionais. Com as peripécias do anti-herói Leonardo Pataca - um boêmio arruaceiro que, por ser constantemente preso, cria amizades no meio militar e, por apadrinhamento, ganha a patente de sargento de milícias - Manuel Antônio de Almeida expõe um "corte sincrônico da vida familiar brasileira nos meios urbanos em uma fase em já se esboçava uma estrutura não mais puramente colonial, mas ainda longe do quadro industrial-burguês" (BOSI, 1985, p. 148), o que, sob o ângulo histórico, garante o valor documental da narrativa, ao mesmo tempo em que, sob o ângulo estético, rompe com padrões e normas do idealismo romântico, ao conferir a um malandro o papel de protagonista da história de vida. A crítica à sociedade e o 
tom picaresco parecem justificar $\mathrm{o}$ fato de que $\mathrm{o}$ texto tenha sido publicado, anonimamente, em folhetins no Correio Mercantil do Rio de Janeiro, entre 1852 e 1853, (RIBEIRO, 2008, p. 54) e, em livro, em 1854, constando a expressão "um brasileiro" no lugar do nome do autor.

O romance Memórias póstumas de Brás Cubas, publicado parceladamente na Revista Brasileira, a partir de março de 1880, e lançado em volume no ano seguinte, apresenta, como núcleo diegético, a vida de Brás Cubas, cujos episódios se estendem do nascimento, em 1805, à morte, em 1869. Com esse romance, Machado de Assis rompe com o paradigma das narrativas de natureza autobiográfica que intentam instituir a veracidade ou a autenticidade do relato, embora aí se encontre o desenho da sociedade brasileira do século XIX. A inovação está sugerida no título - Memórias póstumas de Brás Cubas - devido a sua relação contratual ambígua com o leitor: o fato de as memórias serem póstumas indicia a presença de um sujeito enunciador diverso do sujeito do enunciado, contrariando o caráter memorialístico, que requer a identidade autor-personagem. Paralelamente, o título torna possível a remissão à personagem histórica - Brás Cubas -, fato que acarreta a modificação da natureza do relato. Entretanto, a ambiguidade da enunciação discursiva é desfeita pelo inusitado da dedicatória que apresenta o autor Brás Cubas, um defunto, como autor das Memórias, caracterizando-se 0 texto por prestigiar a ficcionalidade em detrimento da representação do real.

Todavia, Brás Cubas, quando evoca a totalidade de sua vida em busca da autorrevelação, expõe uma conduta individual, dimensionando-a, porém, pelas circunstâncias sociais. Na progressão dos fatos, desnuda seu comportamento, revelando-lhe os secretos motivos, e a interiorização não o induz a atenuar seus defeitos, mas a explicá-los como decorrentes das forças determinísticas vigentes na malha social e, sobretudo, da natureza do homem. Portanto, o conhecimento de si mesmo traz para Brás Cubas o conhecimento da condição humana, de que faz parte enquanto protagonista e de que se desvincula pela situação de defunto-autor. Assim, paradoxalmente, a narrativa de Machado de Assis, ainda que se institua como radicalmente fictícia, representa circunstâncias sócio-históricas do Brasil do século XIX, seja como pano de fundo da diegese, seja como matriz das reflexões críticas do autor 
que expõem um modo de vida contextualizado em um tempo e lugar, para denunciar o vazio da existência humana.

A exposição de costumes e de intensas emoções pessoais é o caminho escolhido por Graciliano Ramos ao compor São Bernardo em que o apelo à memória ganha um espaço relevante, na medida em que o escritor, nas palavras de Antonio Candido (2006, p.17), "percorre o sertão, a mata, a fazenda, a vila, a cidade, a casa, a prisão, vendo fazendeiros e vaqueiros, empregados e funcionários, políticos e vagabundos", compósito que integra "ao seu modo peculiar de julgar e de sentir" para afirmar-se "como artista e como homem". Nesse processo, o escritor cria narrativas autobiográficas em que ora a experiência real é esmaecida pela interferência do poder de persuasão da fantasia, ora a ficção é alimentada pela análise das condições do espaço social que, segundo se depreende da obras, condicionam o modo de ver, de sentir e de pensar das personagens. Entre as narrativas em que Graciliano aborda fatos por ele vividos salientam-se Infância e Memórias do Cárcere: aquela narra os primeiros anos da vida do autor, mas as personagens são apresentadas sob uma ótica romanesca, salientando-se, no plano temático, os sentimentos de opressão e de humilhação impostos pelos adultos a um menino frágil; Memórias do Cárcere é o relato do período, de março de 1936 e janeiro de 1937, em que Graciliano fica encarcerado, como preso político do regime Vargas. Entretanto, o escritor não se restringe à narração dos episódios que lhe causaram sofrimento e humilhação, mas investe também em uma profunda reflexão sobre as motivações humanas, imprimindo ao depoimento um rigor estilístico e um processo narrativo semelhantes aos de sua obra ficcional.

São Bernardo exemplifica a opção de Graciliano Ramos pela narrativa autobiográfica romanesca, mediante a qual alinha sua produção à de Machado de Assis e à de Manuel Antônio de Almeida. O narrador desse romance, Paulo Honório, declarase impotente para escrever sua história, mas, mesmo assim, enfrenta o desafio que, uma vez concluído, the confere uma visão ordenada das coisas e de si mesmo, revelando seu fracasso pessoal. Ele verbaliza a paixão que mobilizara sua vida - o desejo de dominar e de possuir -, que lhe permitira vencer as adversidades e tornar-se o rico proprietário da fazenda São Bernardo, mas que, em contrapartida, o transformara em algoz da esposa, a ingênua professora Madalena, cujo suicídio fora o resultado de 
seu ciúme implacável. Ao valorizar a força e a violência como condições necessárias para a constituição de sua riqueza, Paulo Honório denuncia, também, o mecanismo psíquico que consome e destrói o indivíduo. Esse aspecto, a que se alia a evidente exploração dos recursos da linguagem, confere a São Bernardo a universalidade própria das obras de arte que, ao mimetizarem comportamentos e conflitos humanos, transcendem o localismo e o momento histórico de sua produção de sua produção.

Em sua diversidade, essas diferentes manifestações do biografismo, que se estendem da Antiguidade, tanto da tradição judaico-cristã quanto da história de Roma, à literatura contemporânea, passando pelas produções do século XVIII - quando o individualismo se afirma como concepção de mundo - e pelo século XIX - quando o romance teve seu estatuto estético reconhecido - têm como centro motivador a vida humana e suas relações coletivas, visando conduzir o homem a refletir sobre sua condição. Paralelamente, sob o ângulo de sua escritura, são calcadas na memória e sua forma de representação admite o "tratamento poético de 'sucessos' verdadeiros", enquanto sua função formadora não se restringe "a um testemunho do real, categoria da história, ou à verossimilhança, categoria da poética" (MITIDIERI, 2010, p.51). Essas mesmas produções contribuíram para a afirmação da Literatura como campo distinto de outras expressões humanas e para a definição da especificidade dos gêneros biográfico ou autobiográfico, sem, contudo, deixar de demonstrar a precariedade das fronteiras que separam a narrativa literária da narrativa histórica e da jornalística.

No âmbito da literatura, o espaço biográfico abrange os textos que são elaborados pela emergência da memória, individual ou coletiva, e em que uma vida é contada a partir do princípio da ficcionalidade. Vinculam-se ao gênero produções diversificadas que podem assumir a forma de diários, de cartas, de romances, de contos ou novelas, cujo processo de narração pode abranger a autoconfissão, a convergência de múltiplos pontos de vista que concorrem para conceber o "retrato" do biografado ou o predomínio de uma voz narradora que relata o que presenciou, valendo-se de sua condição de testemunha para legitimar o conhecimento dos fatos.

O caráter ficcional insere o biografismo literário e seus subgêneros, como a biografia e a autobiografia, na ordem da possibilidade e não na da veracidade, tendo em vista que o que é narrado se atém ao que poderia ocorrer e não ao que deve ter 
ocorrido. Portanto, privilegiando a verossimilhança e a necessidade interna, a narrativa biográfica literária distingue-se da biografia histórica e da jornalística, uma vez que essas devem investir na transposição do real e respeitar a veracidade ou, noutras palavras, compor seu discurso de modo a "parecer" verdadeiro, ao passo que aquela assume a ficção como fundamento de sua discursividade.

Todavia, as produções biográficas literárias não deixam de mergulhar na realidade, tampouco se constituem em oposição à verdade, mas elas traduzem "algo cuja alteridade não é compreensível a partir dos hábitos vigentes no mundo da vida" (ISER,1983, p. 397). Assim, embora a ficcionalidade da narrativa biográfica literária possa ser demonstrada, o que a inclui no plano da ficção são convenções, historicamente variadas e determinadas pelas instâncias que institucionalizam o fazer literário, de que autores e público compartilham. Consequentemente, o reconhecimento da ficção designa "o 'contrato' entre autor e leitor, cuja regulamentação o texto comprova não como discurso, mas sim como "discurso encenado" (Iser, 1983, p. 397).

O desnudamento do fingir é, pois, o principal apanágio que distingue a biografia ou a autobiografia literária das biografias históricas e jornalísticas, uma vez que a presença da fantasia e o apelo à imaginação do leitor também nessas coexiste, não sendo possibilitado ao biografismo literário abstrair-se da estruturação de um processo de representação do real.

Paralelamente, a biografia literária, contrariando a biografia histórica e a jornalística, prestigia a multissignificação da linguagem e a criatividade. A conotação peculiar à literatura, ao invés da denotação - própria da história e do jornalismo -, dá lugar a diferentes interpretações de um mesmo texto por diferentes leitores. Essa predominância da conotação é resultado do trabalho de criação inerente à obra de arte, uma vez que os aspectos que a compõem podem transgredir normas comunicativas, tão cuidadosamente observadas em textos não literários, as quais abrangem desde a invenção de novos léxicos até a desestruturação frasal e a criação de imagens metafóricas inusitadas.

Entretanto, se é possível demarcar diferenças entre a narrativa biográfica literária e a histórica ou a jornalística, é preciso salientar, também, o elo comum que as integra: a tentativa, sempre presente, de reter o tempo e de vivificar o passado pela recorrência 
à memória. Disso são exemplos, o romance de Marcel Proust Em busca do tempo perdido - em que o narrador autobiográfico busca capturar um passado inexistente, para dele abstrair a essência do vivido - mas, igualmente, a narrativa histórica As Barbas do Imperador de Lilia Moritz Schwarcz e a biografia jornalística Chatô, o Rei do Brasil de Fernando Morais.

Paralelamente, destaca-se o processo discursivo comum - o ato de narrar - que também contribui para enfatizar a liminaridade entre os campos da Literatura, da História e do Jornalismo, visto que, por seu intermédio, se rompem as fronteiras entre o documento e a invenção, entre a memória e a ficção. Dessa forma, o gênero biográfico ou autobiográfico constitui uma via de reflexão apta a promover a redefinição dos campos do literário, do histórico e do jornalístico e a enriquecer a análise de suas manifestações. 


\section{REFERÊNCIAS}

AZEVEDO, Francisca L. Nogueira de. Biografia e gênero. In: GUAZELLI, César Augusto Barcellos et al (org.) Questões de Teoria e Metodologia da História. Porto Alegre: Editora da Universidade, 2000. p.131-146.

BENJAMIN, Walter. O narrador. Considerações sobre a obra de Nikolai Leskov. In: BENJAMIN, Walter. Magia e técnica, arte e política. São Paulo: Brasiliense, 1985, p.197-221.

BORDIEU, Pierre. A ilusão biográfica. In: FERREIRA, Marieta de Moraes; AMADO, Janaína. Usos e abusos da história oral. 2. ed. Rio de Janeiro: Fundação Getúlio Vargas, 1998. p. 183-191

BOSI. Alfredo. História concisa da literatura brasileira. 3. ed. São Paulo: Cultrix, 1985.

BUARQUE, Daniel. O gênero das multidões. Folha de São Paulo, p.4, 5 dez. 2004.

BURKE, Peter (org.). A Escrita da História. São Paulo: UNESP, 1992.

CANDIDO. Antonio. Ficção e confissão. Ensaios sobre Graciliano Ramos. Rio de Janeiro: Ouro sobre o azul, 2006.

CHARTIER, Roger. A História Cultural entre Práticas e Representações. Lisboa: Difel, 1987.

DOSSE, François. O Desafio Biográfico: Escrever uma vida. São Paulo: Edusp, 2009.

GUARINELLO, Norberto Luiz. História científica, história contemporânea e história cotidiana. Revista Brasileira de História, São Paulo, v.24, n.48, p.13-38, 2004.

LE GOFF, Jacques et al. A Nova História. Lisboa: Edições 70, 1977. 
HAUSER, Arnold. História social da literatura e da arte. Tomo II. 3. ed. São Paulo: Mestre Jou, 1982.

HERÓDOTO. História Fontes digitais. Clássicos Jackson. Tradução J. Brito Broca. Rio de janeiro: W. M. Jackson Inc., 1950. Disponível em:

<http://www.ebooksbrasil.org/eLibris/historiaherodoto.html>.

ISER, Wolfgang. Os atos de fingir ou o que é fictício no texto ficcional. IN: LIMA, Luiz Costa. Teoria da Literatura em suas fontes. Rio de Janeiro: Francisco Alves, 1983.

LEJEUNE. Philippe. Le pacte autobiographique. Paris: Seuil, 1975.

LEVI, Giovanni. Usos da biografia. In: FERREIRA, Marieta de Moraes; AMADO, Janaína. Usos e abusos da história oral. 2. ed. Rio de Janeiro: Fundação Getúlio Vargas,1998. p.167-182.

LORIGA, Sabina. A biografia como problema. In: REVEL, Jacques. Jogos de escalas: a experiência da micro-análise. Rio de Janeiro: Fundação Getúlio Vargas, 1998.

MEYER, Marlyse. Folhetim: uma história. São Paulo: Companhia das Letras, 1996.

MEDEIROS, Márcia Maria de. Romance de cavalaria: tessituras entre arte e mito na literatura medieval. Interdisciplinar, v.7, n.7, p. 137-146, jul/dez 2008. Edição especial.

MEDEIROS, Sílvio. Grécias arcaica e clássica: dos Mestres da Verdade à escuta do Logos. Disponível em: <http://recantodasletras.uol.com.br/teorialiteraria/148686>. Acesso em: 13 out. 2010.

MITIDIERI, André Luis. Como e porque (des)ler os clássicos da biografia. Porto Alegre: IEL;EDIPUCRS, 2010.

PENA, Felipe. Jornalismo Literário. São Paulo: Contexto, 2006.

PEREIRA, Lígia Maria Leite. Algumas reflexões sobre histórias de vida, biografias e autobiografias. História Oral, São Paulo, n.3, p.117-127, jun 2000. 
PEREIRA, Lindjane dos Santos. A biografia no âmbito do jornalismo literário: Análise comparativa das biografias Olga, de Fernando Morais e Anayde Beiriz, paixão e morte na Revolução de 30, de José Joffily. João pessoa: Universidade Federal da Paraíba, 2007. Disponível em: <http://bocc.ubi.pt/pag/pereira-lindjane-jornalismoliterario.pdf>. Acesso em: 12 ago 2009.

RIBEIRO, João Alcides. As seções e gêneros como prática da língua portuguesa nos jornais: Jornal do Commercio e Correio Mercantil. 2008, p.44-60. Disponível em: <http://www.anpoll.org.br/revista/index.php/rev/article/viewFile/54/48>. Acesso em: 30 jan 2011.

RICCI, Magda. Como se faz um vulto na história do Brasil. In: GUAZELLI, César Augusto Barcellos et al(org.) Questões de Teoria e Metodologia da História. Porto Alegre: Editora da Universidade, 2000. p.147-160.

ROJAS, Carlos Antonio Aguirre. La biografia como género historiográfico. Algunas reflexiones sobre sus posibilidades actuales. In: SCHMIDT, Benito (org.) O Biográfico. Perspectivas interdisciplinares. Santa Cruz do Sul: EDUNISC, 2000.

ROSENTHAL, Gabriele. A estrutura e a gestalt das autobiografias e suas conseqüências metodológicas. In: FERREIRA, Marieta de Moraes; AMADO, Janaína. Usos e abusos da história oral. 2. ed. Rio de Janeiro: Fundação Getúlio Vargas, 1998. p.193-200.

SANTO AGOSTINHO. Confissões. São Paulo: Paulus, 2010.

SCHMIDT, Benito Bisso. A biografia histórica: o "retorno" do gênero e a noção de "contexto". In: GUAZELLI, César Augusto Barcellos et al (org.) Questões de Teoria e Metodologia da História. Porto Alegre: Editora da Universidade, 2000. p.121-130.

SCHMIDT, Benito Bisso. Uma reflexão sobre o gênero biográfico: a trajetória do militante socialista Antônio Guedes Coutinho na perspectiva de sua vida cotidiana (1868-1945). 1996. Dissertação (Mestrado) UFRGS, 1996.

SCHMIDT, Benito Bisso. Luz e papel, realidade e imaginação: as biografias na história, no jornalismo, na literatura e no cinema. In: SCHMIDT, Benito (org.) O Biográfico. Perspectivas interdisciplinares. Santa Cruz do Sul: EDUNISC, 2000. 
SCHMIDT, Benito Bisso. Em busca da terra da promissão: a história de dois líderes socialistas. Porto Alegre: Palmarinca, 2004.

SCHMIDT, Benito Bisso. O gênero biográfico no campo do conhecimento histórico: trajetória, tendências e impasses atuais e uma proposta de investigação. Anos 90, Porto Alegre, n.6, 1996.

SCHMIDT, Benito Bisso. Construindo Biografias. Historiadores e Jornalistas: Aproximações e Afastamentos. Estudos Históricos, Rio de Janeiro, n. 19, 1997. Disponível em <http://www.cpdoc.fgv.br/revista/arq/207.pdf>. Acesso em: 07 nov 2008.

SILVA, Andréia Cristina Lopes Frazão da. Hagiografia. Disponível em: <http://www.ifcs.ufrj.br/ frazao/hagiografia.htm>. Acesso em: 20 nov 2010.

SIMÕES, João Gaspar. Breve estudo crítico-biográfico. Disponível em: $<$ http://www.lpmeditores.com.br/artigosnoticias/arquivos/tolstoi estudo critico biografic o.pdf>. Acesso em: 10 jan 2011.

VILAS BOAS, Sergio. Biografias \& Biógrafos: jornalismo sobre personagens. São Paulo: Summus, 2002.

XAVIER, Regina Célia Lima. O desafio do trabalho biográfico. In: GUAZELLI, César Augusto Barcellos et al (org.) Questões de Teoria e Metodologia da História. Porto Alegre: Editora da Universidade, 2000. p.161-173.

ZILBERMAN, Regina. Fim do livro, fim dos leitores? São Paulo: Senac, 2000.

Artigo:

Recebido em: 15/03/2011

Aceito em: 13/06/2011 